\title{
Impact of Tourist Service Quality in Four and Five Stars Hotels in Jordan on Tourist Behavior
}

\author{
Arwa Ahmed Al-Oguiliy \\ Al-balqa Applied University, Jordan \\ E-mail: arwa_oguiliy@yahoo.com.my \\ Dr. Mohammad Shabeeb Khasawneh \\ Assistant Professor, Albalqa Applied University, Jordan
}

Received: March 29, 2015 Accepted: May 4, 2015 Published: June 30, 2015

doi:10.5296/bms.v6i1.7346 URL: http://dx.doi.org/10.5296/bms.v6i1.7346

\begin{abstract}
The study aimed to investigate the impact of service quality on tourist behavior in five and for stars hotels in Jordan. A self administrated questionnaire was designed and distributed over a sample of hotels guest in Amman, the capital amounting 90 guests. The collected data was analyzed the study findings indicated that service quality impact tourists behavior and all service quality dimensions (reliability, responsiveness, assurance, empathy and tangible) also have an impact on tourist behavior. The study suggested some recommendations.
\end{abstract}

Keywords: service quality, Tourist behavior, hotels 


\section{Introduction}

Since the last decades of the last century many service companies have pursued to enhance their performance and effectiveness in search of achieving differentiation in the market. An example of that is the attempt to convince customers that their quality are superior compared

significantly either in developed and developing countries and in the same time research on services has grown also. Academics and practitioners have exhibited considerable interest in issues related measurement of service quality. Many attempts and studies were conducted around the world to discuss service quality for the purpose of investigating its relation different aspects such as customer satisfaction, customer loyalty and other related issues.

Service quality is one of the major issues facing managers but it is an area characterized by debate concerning the need for assessing customer expectations and service quality assessment The importance of service quality has emerged as a fundamental element due to the rapid growth of the services sector and the competition among firms.

With respect to service quality in tourism sector many researcher stated that service quality is a necessary strategy to win the tourism industry in the twenty-first century. On the specific sector of hospitality.

Authors who conducted studies about service quality manifested their concern about the dimensions and methods used to measure service quality in hotels. In Addition to the intrinsic characteristics of the services - heterogeneity, simultaneously, perish ability and intangibility other factors in hospitality industry such as e seasonal demand and imprecise standards. There are three benefits arise from quality: Consumer satisfaction. Superior quality strengths the company's competitiveness by better reputation, more repetitive business and less invisible consumers lost. Productivity/profitability. Decrease of wasted resources due to the lack of quality, which will allow the company to spare costs and enhancements in operations.) Human resources. Employees that provide high-quality services will have a positive attitude toward work environment and better performances. Differentiation through quality protects the business from competitors through enhancing loyalty, decreasing their sensibility to price and avoiding other competitive strengths that reduce price/cost margins.

This study aims to investigate the impact of tourist service quality on tourist behavior.

\section{Research Significance}

The research significance stems from the following:

A-It may provide a baseline data that can be used to set directions in analyzing the impact of tourist service quality on tourist behavior.

B- It may contribute in the growing interest of service quality from the perspective of Jordanian hotel's top management.

C-It many provide the hotel's top management with the latest trends and perspective on 
service quality in tourism industry

\section{Research Questions}

This research is an attempt to answer the following research questions:

1-What is the level of tourist service quality in Jordanian five and four stars hotels?

2-Do Jordanian five and four stars hotels implement service quality dimension?

4-Is there any impact ofservice quality on guest behavior?

\section{Research Objectives}

1-To explore the dimensions of service quality as perceived by hotel's top management in Jordan.

2-To find out the driving factors for implementing service quality in five and four stars Jordanian hotles.

3-To specify the impact of implementing service quality in five and four stars hotels in Jordan on the guest behavior

5. Study Hypotheses

The main hypothesis

Ho1: There is no statistically significance impact of service quality on consumer behavior in five and four stars hotels in Jordan.

The following hypotheses are derived from

Ho1-1: There is no statistically significance impact of reliability on consumer behavior

Ho1-2: There is no statistically significance impact of responsiveness on consumers behavior in five and four stars hotels

Ho1-3: There is no statistically significance impact of assurance on consumer behavior in five and four stars hotels

Ho1-4: There is no statistically significance impact of empathy on consumer behavior in five and four stars hotels

Ho1-5: There is no statistically significance impact of tangibility on consumer behavior in five and four stars hotels

\section{Literature Review}

Last decades witnessed large movement of persons for business and commercial needs. Movement of persons grew and still growing for sightseeing and excursion purposes.The availability of transportation means have resulted into movement of large number of people. All of which leads to increase the demand for lodging and boarding. This has resulted in the 
establishment of hotels. Type of services provided by a typical modern hotel can be broadly classified as primary, secondary and additional services. The primary purpose of a hotel is to provide the customer with lodging and boarding. Secondary services include services which enhance the quality of primary service. It makes the stay in the hotel more enjoyable. The services provided in the secondary services include entertainment services, swimming pool, dance room, gymnasium, games and sports facilities, television, internet, teleconferencing and other business related services and comfortable lobby space. Some additional services were added to the basic hospitality service which include conference room facilities, transportation service, business centre and mail-handling facilities, telephone service in the room, health related service, money changing facility, shopping complex, exhibition rooms and sightseeing service and other services. Every industry nowadays faces increasing competition. Hotel industry is not exception. The availability of many hotel groups in the market indicates that there is a large level of competition. Any hotel, seeks to earn a reasonable rate of return, so, retaining regular customers and attracting new customers are the most priorities for its management. ( Gill and Gill, 2012).

Service quality enables the firm to differentiate itself from its competition, gain a sustainable competitive advantage, and enhance efficiency .Service quality provides the firm with increased customer satisfaction, improved customer retention, positive word of mouth, reduced staff turnover, decreased operating costs, enlarged marketshare, increased profitability, and improved financial performance .

Tourism is considered as the driving force for country development, since tourism can enhance income, employment and government revenues. Therefore providing high service quality for enhancing tourist satisfaction has become an important concern for sustainable tourism destination management (Liu,. and Yen, 2010 ). To be able to attract the tourists to revisit and recommend destinations to others is another important part to build a success of tourism destination development (Chen,. and Tsai, 2007). . Service quality is a measure of how well the level of service delivered matches customer expectations. Hospitality sector is a major service oriented sector in the economy of a nation .

Tourist satisfaction is recognized as one of the key judgments that tourists use to measure tourism services, while future behavior intentions are very closely connected with satisfaction. The expression of satisfaction will result in behavioral responses to recommend, say positive things about and revisit to destinations.

It is well known that visitor retention for all tourism providers, plays a major role in organization's profitability. Behavior is determined by a tourist's intention to perform or not to perform a subjective behavior. Behavioral intentions are defined as the customers' willingness to recommend the service to others and repurchase intent (Zeithaml, Bitner,. and Gremler, 2009). These behavioral intentions can be viewed as positive and negative consequences of service quality. The behavioral intention is determined by attitude toward performing the behavior and subjective norm. Service quality is considered as a predictor for consumer behavior (Lee, Huh, and Hong, 2008) 
The behavioural intentions of customers are recognised in the literature as an important predictor of the profitability of service firms . Both the costs and the revenue of firms are affected by repeat purchases, positive word-of-mouth recommendation, andcustomer feedback. Moreover, there is strong evidence that service quality has either adirect influence on the behavioural intentions of customers and/or an indirect influenceon such intentions, mediated through customer satisfaction (Cronin et al., 2000).

Many researchers have studied the hospitality industry in general and hotel industry in particular regarding the quality of service provided by these organizations

Ivyanno and Nila ( 2012 ) examined the influence of service quality and tourist satisfaction on the future behavioral intentions of domestic local tourists in Borobudur temple Magelang, Central Java Indonesia using SERVQUAL model. The study revealed that service quality has a positive influence on tourist satisfaction and a positive influence also exists between tourist satisfactions on future behavioral intentions. Tangible was the most influencing dimension of service quality.

Abu Ali and Howaidee (2012) study aimed to offer an integrated approach to understanding tourist satisfaction by examining the theoretical and empirical evidence on the causal relationships among the components of tourism product and overall tourist satisfaction. The results supported the proposed model: (1) destination facilities and accessibility and attraction directly influenced tourist satisfaction; (2) there is a significant impact of the service quality on tourist satisfaction.

Gour andTheingi ( 2009)examine the relationships among the constructs of service quality, satisfaction, and behavioural intentions in passengers of three low-cost carriers offering airline services in Thailand. The study found that passenger satisfaction with service-quality dimensions is very important in explaining behavioural intentions.. Such customers engage in positive word-of-mouth communication and have high repurchase intentions. Dissatisfied passengers prefer to change airlines, rather than provide feedback to the company.

Ladhar ( 2009 ) study aimed to develop and test a conceptual model of the relationships among the constructs of "service quality", "emotional satisfaction", and "behavioural intention" in the hospitality industry. The study results confirm that service quality exerts both direct and indirect effects (through emoti onal satisfaction) on behavioural intentions.

Akbaba (2006) has said that the role of service quality in the success of hotel businesses cannot be denied. It is vital for the hotel managers to have a good understanding on what exactly the customers want.

McCaina and Shiang-Lih (2005) conducted a gap analysis between loyal customers and potential switchers in evaluating service quality attributes. They found that the top three gaps were all related to the functional quality (interactions between customers, and employees), not technical quality and customer relation

Raymond and Choi (2001) examined the relative importance of hotel factors in relation to 
travelers ${ }^{\text {ee }}$ overall satisfaction levels with their hotel stays in Hong Kong and the likelihood of returning to the same hotels in their subsequent trips., They found that staff Service Qualityee, „Room Qualitiese and „Value ${ }^{e e}$ were the three most influential factors in determining travelers ${ }^{e e}$ overall satisfaction levels and their likelihood of returning to the same hotels

\section{Methodology}

The study used the methodology that can help in investigating the impact of tourist service quality on tourist behaviour. All needed data were collected through using different means and methods .So the methodology that was followed included the research approach, data collection methods, questionnaire design and analysis approaches used for data analysis..

\subsection{Research Approach}

There are two types of research approaches namely: qualitative and quantitative. Qualitative approach concerned with collecting and analyzing non numeric data ., it includes the use of field observations, focus groups and in-depth interviews it deals with how people understand their experiences. The second type is the quantitative approach which aims to develop and employ mathematical models, theories and hypotheses related the studied phenomena .

\subsection{Questionnaire Design}

The questionnaire was designed in three parts, the first part is the covering letter in which research objective is mentioned In addition the covering letter assured sample's individuals that their responses will be confidential. The second part consists of questions related to demographic data such as ( gender, age, educational level, job title and years of experience ). The third part will include the statements that evaluate the image destination through using the SERVQUAL . Likert scale of five points will be applied that is: strongly agree $=5$, agree $=4$, neutral $=3$, disagree $=2$ and strongly disagree $=1$. Two versions of the questionnaire will be handed to the sample. Arabic and English version mainly was handed to those who don't master the English language, While the English version was handed to those who don't master the Arabic language The questionnaire will be distributed in person

\subsection{Population and Sampling}

The study population consists of all tourists who are visiting Jordan in the period of implementing the survey. Hotel's guests were chosen to provide their views regarding the impact of service quality on guest behaviors. The non-probability convenience sampling was employed as the purpose of the study is to explore the multiple dimensions of service quality in five and four stars hotels in Jordan rather than to generalize the findings to a wider population

\subsection{Demographic Analysis}

The analysis of the collected data from the responding sample revealed the following results in terms of sample, gender, age, educational level, and type of visit: 
Table 1. Sampling Distribution by Demographic Variables

\begin{tabular}{|l|l|l|l|}
\hline Variable & Option & Frequency & Percent \\
\hline Gender & Male & 51 & 52.0 \\
\cline { 2 - 4 } & Female & 47 & 48.0 \\
\hline \multirow{5}{*}{ Age Group } & Less than 25 years & 15 & 15.3 \\
\cline { 2 - 4 } & 25 to less than 35 years & 35 & 35.7 \\
\cline { 2 - 4 } & 35 to less than 45 & 24 & 24.5 \\
\cline { 2 - 4 } & $45+$ years & 24 & 24.5 \\
\hline Education Level & Secondary or less & 53 & 54.1 \\
\cline { 2 - 4 } & Bachelor degree & 38 & 38.8 \\
\cline { 2 - 4 } Type of visit & Master Degree & 7 & 7.1 \\
\hline & Tourist & 37 & 37.8 \\
\cline { 2 - 4 } & Business & 48 & 49 \\
\cline { 2 - 4 } & Medical & 13 & 13.2 \\
\hline
\end{tabular}

Table (1) indicates that $52 \%$ of the sample were males and $48 \%$ were females... With respect to sample respondents' age, $(15.3 \%)$ of the respondents their age is less than 25 years. $35.7 \%$ of the sample their age ranged between 35 to less than 35 years, while $24.5 \%$ of the sample their age ranged between (35to less than 45 and 45 +years old.. A majority of the respondents $(54.1 \%)$ have secondary school, while $45.9 \%$ have university degree... With respect to type of visit, $37.8 \%$ of the sample have tourist visit. $49 \%$. Have business visit

Data Analysis

The following scores were used for assessing sample's responses. Likert scale of five scores was used, so to find the samples level of agreement the following computation was used:

$5 \div 3=1.33$

$1+1.33=2.33$ Low

$2.34+1.33=3.67$ Medium

3.67 And more $=$ High

Table 2. Means and Standard Deviations for Sample Responses regarding reliability dimension

\begin{tabular}{|c|l|r|r|c|c|}
\hline No & \multicolumn{1}{|c|}{ Statements } & \multicolumn{1}{|c|}{ Mean } & \multicolumn{1}{c|}{ S. D. } & Rank & Degree \\
\hline 1 & $\begin{array}{l}\text { When hotel promises to do something by } \\
\text { a certain time, it does so }\end{array}$ & 3.84 & 1.042 & 2 & High \\
\hline 2 & $\begin{array}{l}\text { When you have a problem, hotel shows a } \\
\text { sincere interest in solving it }\end{array}$ & 3.90 & .947 & 1 & High \\
\hline 3 & $\begin{array}{l}\text { Hotel performs the service right the first } \\
\text { time. }\end{array}$ & 3.54 & 1.123 & 4 & Medium \\
\hline 4 & $\begin{array}{l}\text { Hotel provides its service at the time it } \\
\text { promises to do so. }\end{array}$ & 3.71 & .984 & 3 & High \\
\hline 5 & Hotel insists on error free records & 3.40 & 1.199 & 5 & Medium \\
\hline
\end{tabular}


Reliability dimension was measured by statements (1-5) from sample's perspective. It is clear from table (2) that study sample attitudes regarding reliability means ranged between $(3.40-$ 3.90). All of which indicate different degree of positive attitudes of the sample towards reliability. Furthermore, statement no.(2) which states" When you have a problem, hotel shows a sincere interest in solving it " ranked the first, while statement no.(5) which states that" Hotel insists on error free records" ranked the last.

Table 3. Means and Standard Deviations for Sample Responses regarding Responsiveness dimension

\begin{tabular}{|c|l|r|r|c|c|}
\hline No & \multicolumn{1}{|c|}{ Statements } & Mean & \multicolumn{1}{|c|}{ S. D. } & Rank & Degree \\
\hline 6 & $\begin{array}{l}\text { Employees in hotel tell you exactly when } \\
\text { services will be performed }\end{array}$ & 3.87 & 1.012 & 3 & High \\
\hline 7 & $\begin{array}{l}\text { Employees in hotel give you prompt } \\
\text { service }\end{array}$ & 3.89 & .951 & 2 & High \\
\hline 8 & $\begin{array}{l}\text { Employees in hotel are always willing to } \\
\text { help you }\end{array}$ & 3.63 & 1.039 & 5 & Medium \\
\hline 9 & $\begin{array}{l}\text { Employees in hotel are never too busy to } \\
\text { respond to your request }\end{array}$ & 4.03 & .968 & 1 & High \\
\hline 10 & $\begin{array}{l}\text { Employees in hotel provide you with } \\
\text { information you need. }\end{array}$ & 3.84 & .927 & 4 & High \\
\hline
\end{tabular}

Responsiveness dimension was measured by statements (6-10) from sample's perspective. It is clear from table (3) that study sample attitudes regarding responsiveness means ranged between $(3.63-4.03)$. All of which indicate different degree of positive attitudes of the sample towards responsiveness. Furthermore, statement no.(9) which states" Employees in hotel are never too busy to respond to your request" ranked the first, while statement no.(8) which states that" Employees in hotel are always willing to help you" ranked the last.

Table 4. Means and Standard Deviations for Sample Responses regarding Assurance dimension

\begin{tabular}{|c|l|c|r|r|c|}
\hline No & \multicolumn{1}{|c|}{ Statements } & Mean & \multicolumn{1}{|c|}{ S. D. } & Rank & Degree \\
\hline 11 & $\begin{array}{l}\text { The behavior of employees in hotel } \\
\text { instills confidence in you }\end{array}$ & 1 & .913 & 4.03 & High \\
\hline 12 & You feel safe with this hotel. & 3 & .927 & 3.84 & High \\
\hline 13 & $\begin{array}{l}\text { Employees in hotel consistently courteous } \\
\text { with you }\end{array}$ & 2 & 1.032 & 3.81 & High \\
\hline 14 & $\begin{array}{l}\text { Employees in hotel have the knowledge to } \\
\text { answer your questions }\end{array}$ & 4 & 1.123 & 3.54 & Medium \\
\hline
\end{tabular}

Assurance dimension was measured by statements (11-14) from sample's perspective. It is clear from table (4) that study sample attitudes regarding assurance means ranged between (3.54 - 4.03). All of which indicate different degree of positive attitudes of the sample towards assurance. Furthermore, statement no.(1) which states" The behavior of employees in hotel instills confidence in you " ranked the first, while statement no.(4) which states that" Employees in hotel have the knowledge to answer your questions" ranked the last. 
Table 5. Means and Standard Deviations for Sample Responses regarding Empathy dimension

\begin{tabular}{|c|l|c|c|c|c|}
\hline No & \multicolumn{1}{|c|}{ Statements } & Mean & S. D. & Rank & Degree \\
\cline { 2 - 6 } 15 & Hotel gives you individual attention. & 1 & 1.040 & 3.90 & \\
\hline 16 & $\begin{array}{l}\text { Hotel has operating hours convenient to } \\
\text { all its customers }\end{array}$ & 2 & 1.035 & 3.80 & \\
\hline 17 & $\begin{array}{l}\text { Hotel has employees who give you } \\
\text { personal attention }\end{array}$ & 3 & 1.075 & 3.76 & \\
$\begin{array}{l}\text { The employees of this understand your } \\
\text { specific needs }\end{array}$ & 4 & 1.212 & 3.64 & \\
\hline
\end{tabular}

Empathy dimension was measured by statements (15-18) from sample's perspective. It is clear from table (5) that study sample attitudes regarding empathy means ranged between (3.64 - 3.90). All of which indicate different degree of positive attitudes of the sample towards empathy. Furthermore, statement no. (15) Which states" Hotel gives you individual attention" ranked the first, while statement no. (18) which states that" The employees of this understand your specific needs" ranked the last.

Table 6. .Means and Standard Deviations for Sample Responses regarding Tangibility

\begin{tabular}{|c|l|r|r|c|c|}
\hline No & Statements & Mean & S. D. & Rank & Degree \\
\hline 19 & Hotel has modern looking equipment. & 3.88 & 1.115 & 1 & High \\
\hline 20 & $\begin{array}{l}\text { Hotel's physical facilities are visually } \\
\text { appealing }\end{array}$ & 3.53 & 1.159 & 3 & Medium \\
\hline 21 & $\begin{array}{l}\text { Hotel's reception desk employees are } \\
\text { neat appearing }\end{array}$ & 3.47 & 1.203 & 4 & Medium \\
\hline 22 & $\begin{array}{l}\text { Materials associated with the service are } \\
\text { visually appealing at hotel }\end{array}$ & 3.65 & 1.194 & 2 & Medium \\
\hline
\end{tabular}

Tangibility dimension was measured by statements (19-22) from sample's perspective. It is clear from table (6) that study sample attitudes regarding tangibility means ranged between (3.47 - 3.88). All of which indicate different degree of positive attitudes of the sample towards tangibility. Furthermore, statement no. (19) which states" Hotel has modern looking equipment " ranked the first, while statement no.(21) which states that" Hotel's reception desk employees are neat appearing " ranked the last.

Table 7. Means and Standard Deviations for Sample Responses regarding consumer behavior

\begin{tabular}{|c|l|r|r|c|c|}
\hline No & Statements & Mean & S. D. & Rank & Degree \\
\hline 23 & Repeating the visit to the hotel & 3.89 & 1.120 & 1 & High \\
\hline 24 & Increase your stay in the hotel & 3.55 & 1.176 & 4 & Medium \\
\hline 25 & Recommend the hotel to your friends & 3.51 & 1.220 & 5 & Medium \\
& & & & & \\
\hline 26 & Never switch to other hotel & 3.69 & 1.222 & 2 & High \\
\hline 27 & Promote the hotel service & 3.64 & 1.186 & 3 & Medium \\
\hline
\end{tabular}

Consumer behavior dimension was measured by statements (23-27) from sample's perspective. It is clear from table (7) that study sample attitudes regarding consumer behavior 
means ranged between $(3.51$ - 3.89). All of which indicate different degree of positive attitudes of the sample towards consumer behavior. Furthermore, statement no.(23) which states" Repeating the visit to the hotel" ranked the first, while statement no.(25) which states that" Recommend the hotel to your friends" ranked the last.

\section{Hypotheses Testing}

Many statistical tests were used to test study hypotheses. The obtained results are as follows;

Ho1: There is no statistically significance impact of service quality on consumer behavior in five and four stars hotels in Jordan.

Table 8. Results of first main hypothesis

\begin{tabular}{|c|c|c|c|c|c|c|}
\hline $\begin{array}{c}\text { Dependent } \\
\text { Variable }\end{array}$ & $\mathrm{R}$ & $\mathrm{R}^{2}$ & $\begin{array}{c}\text { F-Calculate } \\
\mathrm{d}\end{array}$ & $\mathrm{DF}$ & Sig & $\begin{array}{c}\text { Index. } \\
\text { variable }\end{array}$ \\
\hline Consumer & 0.984 & .969 & 575.850 & 5 & 0.00 & Service quality \\
& & & & 92 & 0 & \\
& & & & 97 & & \\
\hline
\end{tabular}

Table (2 )indicates the simple regression model which represent the relation between service quality from one hand and consumer behavior from the other hand is significant since $\mathrm{F}$ calculated value $=575.850$ and Sig. Value is $(0.000)$. Moreover service quality explains 96.9\% of the changes in consumer behavior and represents the impact of the independent variable (service quality) on the dependent variable. Therefore the null hypothesis is rejected and the alternative one is accepted. This means that there is statistically significant impact of service quality on consumer behavior.

Ho1-1: There is no statistically significance impact of reliability on consumer behavior

Table 9. Test results of first sub-hypothesis

\begin{tabular}{|c|c|c|c|c|c|c|c|c|}
\hline $\begin{array}{c}\text { Dependent } \\
\text { Variable }\end{array}$ & $\mathrm{R}$ & $\mathrm{R}^{2}$ & $\begin{array}{c}\mathrm{F}-\text { Calculate } \\
\mathrm{d}\end{array}$ & $\mathrm{DF}$ & $\mathrm{Sig}$ & $\begin{array}{c}\text { Indep. } \\
\text { Variable }\end{array}$ & $\begin{array}{c}\mathrm{T} \\
\text { Calculated }\end{array}$ & Sig \\
\hline $\begin{array}{c}\text { Consumer } \\
\text { behavior }\end{array}$ & .562 & .316 & 44.259 & 1 & $\begin{array}{c}0.00 \\
0\end{array}$ & Reliability & 6.653 & 0.00 \\
\cline { 2 - 8 } & & & & 98 & & & & 0 \\
\cline { 2 - 8 } & & & & 99 & & & & \\
\hline
\end{tabular}

Table (9) results indicate that $(\mathrm{R}=0.562)$, this means that there is a strong relationship[ between independent variable ( reliability ) and dependent variable ( consumer behavior). Moreover the tables indicate that $\left(\mathbf{R}^{2}=0.316\right)$, this means that reliability variable explains $(31.6 \%)$ variance in consumer behavior.The table also shows that $F$ value is (44.259) at $(\mathrm{Sig}=0.000)$ level, which confirms the regression significant at $(\boldsymbol{\alpha} \leq 0.05)$. Table indicates that $(\mathrm{T}=6.653)$ at $(\mathrm{Sig}=0.000)$ confidence level, therefore the null hypothesis is rejected and the alternative one is accepted, so there is statistically significance impact of reliability on consumer behavior.

Ho1-2: There is no statistically significance impact of responsiveness on consumers behavior in five and four stars hotels 
Table 10. Test results of second sub-hypothesis

\begin{tabular}{|c|c|c|c|c|c|c|c|c|}
\hline $\begin{array}{c}\text { Depend } \\
\text { ent } \\
\text { Variabl } \\
\mathrm{e}\end{array}$ & $\mathrm{R}$ & $\mathrm{R}^{2}$ & $\begin{array}{c}\mathrm{F}-\mathrm{Calculate} \\
\mathrm{d}\end{array}$ & $\mathrm{DF}$ & Sig & $\begin{array}{c}\text { Indep. } \\
\text { Variable }\end{array}$ & $\begin{array}{c}\mathrm{T} \\
\text { Calculated }\end{array}$ & Sig \\
\hline $\begin{array}{c}\text { Consu } \\
\text { mer } \\
\text { behavi } \\
\text { or }\end{array}$ & .596 & .355 & 85.926 & 1 & 0.000 & $\begin{array}{c}\text { Responsiven } \\
\text { ess }\end{array}$ & 7.275 & $\begin{array}{c}0.00 \\
0\end{array}$ \\
\cline { 2 - 9 } & & & & 98 & & & & \\
\hline
\end{tabular}

Table (10) results indicate that $(\mathrm{R}=0.596)$, this means that there is a strong relationship between independent variable (responsiveness) and dependent variable (consumer behavior).Moreover the tables indicate that $\left(\mathbf{R}^{2}=0.355\right)$, this means that responsiveness variable explains $(35.5 \%)$ variance in consumer behavior. The table also shows that $F$ value is (85.926) at $(\mathrm{Sig}=0.000)$ level, which confirms the regression significant at $(\boldsymbol{\alpha} \leq 0.05)$. Table indicates that $(\mathrm{T}=7.275)$ at $(\mathrm{Sig}=0.000)$ confidence level, therefore the null hypothesis is rejected and the alternative one is accepted, so there is a statistically significance impact of responsiveness on consumer behavior.

Ho1-3: There is no statistically significance impact of assurance on consumer behavior in five and four stars hotels

Table 11. Test results of third sub-hypothesis

\begin{tabular}{|c|c|c|c|c|c|c|c|c|}
\hline $\begin{array}{c}\text { Depe } \\
\text { ndent } \\
\begin{array}{c}\text { Varia } \\
\text { ble }\end{array}\end{array}$ & $\mathrm{R}$ & $\mathrm{R}^{2}$ & $\begin{array}{c}\text { F-Calculate } \\
\mathrm{d}\end{array}$ & $\mathrm{DF}$ & $\mathrm{Sig}$ & $\begin{array}{c}\text { Indep. } \\
\text { Variable }\end{array}$ & $\begin{array}{c}\mathrm{T} \\
\text { Calculated }\end{array}$ & Sig \\
\hline $\begin{array}{c}\text { Cons } \\
\text { umer } \\
\text { behav } \\
\text { ior }\end{array}$ & .689 & .475 & 86.920 & 1 & $\begin{array}{c}0.00 \\
0\end{array}$ & Assurance & 9.323 & $\begin{array}{c}0.00 \\
0\end{array}$ \\
\cline { 2 - 9 } & & & & 98 & & & & \\
\hline
\end{tabular}

Table (10) results indicate that $(\mathrm{R}=0.689)$, this means that there is a strong relationship between independent variable (assurance) and dependent variable (consumer behavior).Moreover the tables indicate that $\left(\mathbf{R}^{2}=0.475\right)$, this means that responsiveness variable explains $(74.5 \%)$ variance in consumer behavior. The table also shows that $F$ value is (86.920) at $(\mathrm{Sig}=0.000)$ level, which confirms the regression significant at $(\boldsymbol{\alpha} \leq 0.05)$. Table indicates that $(\mathrm{T}=9.323)$ at $(\mathrm{Sig}=0.000)$ confidence level, therefore the null hypothesis is rejected and the alternative one is accepted, so there is a statistically significance impact of assurance on consumer behavior.

Ho1-4: There is no statistically significance impact of empathy on consumer behavior in five and four stars hotels 
Table 12. Test results of fourth sub-hypothesis

\begin{tabular}{|c|c|c|c|c|c|c|c|c|}
\hline $\begin{array}{c}\text { Dependent } \\
\text { Variable }\end{array}$ & $\mathrm{R}$ & $\mathrm{R}^{2}$ & $\begin{array}{c}\text { F-Calculate } \\
\mathrm{d}\end{array}$ & $\mathrm{DF}$ & $\mathrm{Sig}$ & $\begin{array}{c}\text { Indep. } \\
\text { Variabl } \\
\mathrm{e}\end{array}$ & $\begin{array}{c}\mathrm{T} \\
\text { Calcula } \\
\text { ted }\end{array}$ & Sig \\
\hline $\begin{array}{c}\text { Consumer } \\
\text { behavior }\end{array}$ & .601 & .361 & 54.312 & 1 & $\begin{array}{c}0.00 \\
0\end{array}$ & $\begin{array}{c}\text { empath } \\
\mathrm{y}\end{array}$ & 7.370 & 0.000 \\
\cline { 2 - 9 } & & & & 98 & & & & \\
\cline { 2 - 9 } & & & & 99 & & & & \\
\hline
\end{tabular}

Table (12) results indicate that $(\mathrm{R}=0.601)$, this means that there is a strong relationship between independent variable (empathy) and dependent variable (consumer behavior).Moreover the tables indicate that $\left(\mathbf{R}^{2}=0.361\right)$, this means that empathy variable explains (39.1\%) variance in consumer behavior. The table also shows that $\mathrm{F}$ value is $(54.312)$ at $(\mathrm{Sig}=0.000)$ level, which confirms the regression significant at $(\boldsymbol{\alpha} \leq 0.05)$. Table indicates that $(\mathrm{T}=7.370)$ at $(\mathrm{Sig}=0.000)$ confidence level, therefore the null hypothesis is rejected and the alternative one is accepted, so there is a statistically significance impact of empathy on consumer behavior.

Ho1-5: There is no statistically significance impact of tangibility on consumer behavior in five and four stars hotels

Table 13. Test results of fifth sub-hypothesis

\begin{tabular}{|c|c|c|c|c|c|c|c|c|}
\hline $\begin{array}{c}\text { Dependent } \\
\text { Variable }\end{array}$ & $\mathrm{R}$ & $\mathrm{R}^{2}$ & $\begin{array}{c}\text { F-Calculate } \\
\mathrm{d}\end{array}$ & $\mathrm{DF}$ & $\mathrm{Sig}$ & $\begin{array}{c}\text { Indep. } \\
\text { Variabl } \\
\mathrm{e}\end{array}$ & $\begin{array}{c}\mathrm{T} \\
\text { Calcul } \\
\text { ated }\end{array}$ & $\mathrm{Sig}$ \\
\hline $\begin{array}{c}\text { Consumer } \\
\text { behavior }\end{array}$ & .984 & .968 & 2905.156 & 1 & $\begin{array}{c}0.00 \\
0\end{array}$ & $\begin{array}{c}\text { tangibil } \\
\text { ity }\end{array}$ & $\begin{array}{c}53.90 \\
0\end{array}$ & $\begin{array}{c}0.00 \\
0\end{array}$ \\
\cline { 2 - 9 } & & & & 98 & & & & \\
\cline { 2 - 8 } & & & & 99 & & & & \\
\hline
\end{tabular}

Table (13) results indicate that $(\mathrm{R}=0.984)$, this means that there is a strong relationship between independent variable (tangibility) and dependent variable (consumer behavior).Moreover the tables indicate that $\left(\mathbf{R}^{2}=0.968\right)$, this means that empathy variable explains $(96.8 \%)$ variance in consumer behavior. The table also shows that $\mathrm{F}$ value is $(2905.156)$ at $(\mathrm{Sig}=0.000)$ level, which confirms the regression significant at $(\boldsymbol{\alpha} \leq 0.05)$. Table indicates that $(\mathrm{T}=53.900)$ at $(\mathrm{Sig}=0.000)$ confidence level, therefore the null hypothesis is rejected and the alternative one is accepted, so there is a statistically significance impact of tangibility on consumer behavior.

\section{Results and Discussions}

Based on the above mentioned analysis the study concluded the following

1-service quality impacts consume behavior in four stars hotels in Jordan and this results agree with previous studies that handled such topics

2-The fifth dimensions of service quality impact separately consumer behavior in four stars hotels in Jordan 


\section{Macrothink}

The study recommended the following;

3-Hotels managements have to find the possible and ways to improve in their operation their services quality either by qualified human or by employing advanced technology.

4 -To improve and develop service quality level provided

By hotels to meet consumers expectations through setting a comprehensive and full plan to develop all service aspects

\section{References}

Akbaba, A. (2006). Measuring service quality in the hotel industry: A study in a business hotel in Turkeye, International Journal of Hospitality Management, 25(2), 170-192.

Chen, C. F., \& Tsai, D. (2007). How Destination Image and Evaluative Factors Affect Behavioral Intentions. Tourism Management, 28, 1115-1122.

Gill, A. K., \& Gill, S. S. (2012). Quality of Service in Hospitality Industry: An Empirical Stud World, Review of Business Research, 2(3), 162-173.

Gour, C. S., \& Theingi (2009), Service quality, satisfaction, andbehavioural intentions. A study of low-cost airline carriers in Thailand. Managing Service Quality, 19(3), 350-372. http://dx.doi.org/10.1108/09604520910955348

Ivyanno, C., \& Nila, H. (2012) Behavioral Intentions: The Case Study of Borobudur Temple as a UNESCO World Culture Heritage Destination, IPEDR. 2. V50. 19

Jihad, Abu Ali, \& Majeda, H. (2012). The Impact of Service Quality on Tourist Satisfaction in Jerash. Institute of Interdisciplinary Business Research, 3(12).

Ladhari, R. (2009). Service quality, emotional satisfaction, and behavioral intentions A study in the hotel industry.

Lee, S., Huh, J., \& Hong, S. (2008). Determining Behavioral Intention To Visit A Festival Among First-Time and Repeat Visitors. International Journal of Tourism Sciences, 8(1), $39-55$.

Liu, C. H., \& Yen, L. C. (2010). The Effects of Service Quality, Tourism Impact, and Tourist Satisfaction on Tourist Choice of Leisure Farming Types. African Journal of Business Management, 4(8), 1529-1545.

Raymond, C., \& Choi, T. Y. (2001). Determinants of hotel guests. satisfaction and repeat patronage in the Hong Kong hotel industry. International Journal of Hospitality Management, 20(3), 277-297.

Zeithaml, V. A., Bitner, M. J., \& Gremler, D. D. (2009). Services Marketing: Integrating Customer Focus Across the Firm. 5th ed. New York: McGraw-Hill. 


\section{Copyright Disclaimer}

Copyright for this article is retained by the author(s), with first publication rights granted to the journal.

This is an open-access article distributed under the terms and conditions of the Creative Commons Attribution license (http://creativecommons.org/licenses/by/3.0/). 